\title{
THE UEVELOPMENT OF THE CONCEPTACLE IN FUCUS
} CONTRIBUTIONS FROM THE HULL BOTANICAL LABORATORY 2 I2

\author{
Mabel Lewis Roe
}

(WITH PLATES XIV-XVII)

\section{Introduction}

When engaged upon a study of Splachnidium rugosum, the writer was forced to work out a new theory for the development of the conceptacle, since methods previously described did not offer sufficient explanation for what was found in Splachnidium. It seemed probable that such might also be the case in more advanced members of the Fucaceae, particularly Fucus, and it was with this in mind that a re-examination of this well-known form was undertaken. The results have proved interesting enough to warrant the reinvestigation.

\section{Material and methods}

For the material the writer is greatly indebted to Professor Charles J. Chamberlain, who had at his disposal paraffin cakes of young tips of Fucus edentatus Delapyl. and Kjellman ( $F$. furcatus Agardh et al.) and of Fucus vesiculosus L., of which he had also mature tips containing ripe conceptacles. In addition, he furnished the writer entire plants of Splachnidium rugosum Grev., collected by him at Glen Cairn, near Cape Town, South Africa. To Professor John M. Coulter the writer is indebted for material of Fucus serratus L., which was collected at Pictou, N.S., by Mr. J. Crerar McDonald, at the request of Professor W. G. Farlow. All the material, except that used for fig. 20 , was cut $5^{-8 \mu}$ in thickness, parallel to the long axis and at right angles to the flat surface of the thallus. Material for fig. 20 was cut I $_{5} \mu$ thick. The sections were stained with Haidenhain's iron alum haematoxylin and given a light touch before mounting with Grübler's Lichtgrün dissolved in equal parts of absolute alcohol and clove oil. The former stain brought out nuclear and cytoplasmic detail, while the latter gave in sharp relief all cell walls and layers of mucilage. 


\section{Previous work}

The first attempt at detailed, histological description of the origin of the conceptacle was that of KüTZING in I843 (13). He speaks there (p. 92) of the appearance on the surface of the thallus of small circular depressions, "Fasergrübchen" (cryptostomata), which have a raised border and contain finely septate ("gegliederte") hairs. He says that in their structure they resemble conceptacles ("Hüllenfrüchte") and seem to have a certain relation to them, although present in certain forms which do not possess conceptacles. Moreover, they appear on sterile as well as on fertile plants. He reports them sometimes lacking on Fucus vesiculosus, although usually present. He offers an ingenious explanation of the use of hairpits to the plant, describing a fusion of hairs developing a new plantlet as an adventitious shoot upon the parent.

$\mathrm{He}$ calls the conceptacle a closed-over sorus ("eingestülpter Sorus") and says (p. 98) that the layer forming the inner wall of the cavity is nothing other than a slight modification of the superficial layer of the cortex which becomes covered over and bears antheridia and paraphyses ("Samen und Nebenfäden trägt"). This cover conforms in structure to that of the superficial layer ("Rindenschicht") of the thallus.

AgARDH in 1848 (2) describes in the Fucoideae (p. 2) superficial cells prolonged into hairs, which project freely beyond the surface of the frond, either scattered or massed in a small bundle; this bundle is bounded by an elevated margin of adjacent cells. Such a body he calls a "cryptostomatum." The conceptacles ("scaphidia") he describes as suspended in the anastomosing filaments in the interior of the thallus, and hollowed out beneath the surface (p. I8I). In the same place he mentions the occurrence of hairpits ("cryptae minutae") on sterile portions of the frond which are analagous to conceptacles on fertile parts ("scaphidiis in parte fertili analogae"), but that such "crypts" are often lacking. He describes a thin membrane in the early stage covering the mouth of the cavity which is a portion of the superficial layer ("quae tantum pars strati superficialis est"), but that the mouth of the cavity is later always open ("sed demum eadum semper evadunt ostiolo hiantia"). 
SACHS in 1875 (26) says (p. 227) of the conceptacle of the Fucaceae:

"These conceptacles are not formed in the interior of the tissue, but as depressions in the surface which become walled in by the surrounding tissue, and so overgrown that at length only a narrow channel remains, opening outward. The layer of cells which clothes the hollow is thus a continuation of the external epidermal layer of the thallus, and since the filaments which produce the antheridia and oogonia sprout from these, these latter are, morphologically, trichomes."

In the same year ReInke (2I) published an account of Fucus vesiculosus, followed a year later by a much more inclusive record of investigations (22) of a large number of closely related genera. In each paper he discusses the origin and development of both hairpits ("Fasergrübchen") and conceptacles. On p. 337 he gives the details. The first indication of a pit is noticed on the lip close to the growing point, where a few neighboring epidermal cells separate themselves from other tissue (comparable to formation of resin ducts in conifers) and form between them an intercellular space filled with mucilaginous substance. Also the cortical cells, just beneath, are involved in this separation, and the cavity thus developed widens into flask-form, wherein the original meristematic cells take on the usual character of the border cells. These border cells develop first into papillae, and by subsequent division into hairs which project beyond the mouth of the pit.

The conceptacle is regarded by REINKE as a structure comparable to the flower of angiosperms, and is a metamorphosed thallus apex and branches. In this metamorphosis hairpits are changed into conceptacles (p. 338). The details of development are about as in the hairpit (p. 339). On the exterior the cavity is rendered firm by the epidermis and a few layers of cortical tissue. The epidermis stops short at each side of the ostiole; the walls are formed by small, nearly isodiametric cells corresponding to the cortex. Hairs spring from the base of the cavity and project beyond the ostiole. Because of the place of origin (close to the growing point) and similarity in method of development (separation of groups of cells from adjacent external cells, etc.), he considers the conceptacle the homologue of the hairpit (p. 340), and 
that up to a certain stage there is no recognizable difference between the two ("auf diesem Stufe giebt es keinen erkennbaren Unterschied zwischen Fasergrübchen und Conceptaculum; wir haben es mit der Erscheinung zu thun dass ein der Anlage nach identisches Organ sich in einem Fall zu vegetativen, im anderen Fall zu reproductiver Thätigkeit entwickelt").

The next important contribution to this subject was the paper by BOWER in I880 (6), whose work has been generally accepted since. In his introduction he gives a very brief résumé of previous work, given in the foregoing in greater detail. He first describes the development of the conceptacle and then compares it with that of the hairpit, which he regards "as an incomplete sexual conceptacle" (p. 37). He agrees with Rostafinski (25) as to behavior of segments of the apical cell, namely, that each segment divides first by a wall parallel to its free surface; the outer cell again divides in two planes at right angles to each other and to the first wall, thus giving four cells which may repeat the same method of segmentation as the original segment. A slight modification of this behavior initiates a conceptacle (or hairpit). Upon completion of a linear series of cells, activity in horizontal division ceases, leaving the terminal ("initial") cell in a depression as surrounding tissue continues active growth. This "initial" first loses its internal tension and later shrinks back against the basal segment beneath. Later segments of this basal portion (cortical in origin) line the bottom of the cavity, whereas the sides are derived from the limiting tissue (external layer) and from subjacent cortical tissue. This is the method for Fucus.

In Himanthalia (pp. 46,48 ), the lining of the cavity is derived entirely from limiting tissue. In Halidrys he finds (p. 45) that

"The basal cell divides at first by walls strongly inclined to one another. The cells thus produced do not at any early stage divide by walls parallel to the surface of the cavity. The result is that the conceptacle usually appears .... as though lined by a layer of cells continuous with the limiting layer; but as part, at least, of this tissue is derived from the basal cell, this conclusion is inadmissible. Meanwhile the initial cell (or group of cells) has been completely thrown off by the swelling of the wall dividing it from the basal cell. Later, as in other plants of this group, the calls of the lining tissue put forth papillae which develop further into hairs." 
Bower pays considerable attention to the "central column."

"The change of the substance filling the cavity has advanced so far that the unaltered portion immediately surrounding the remnants of the initial cell forms a central column of irregular outline. This stretches from the basal cell to the neck of the coneeptacle, and is connected with the walls of the conceptacle by thin strings, which, like itself, have remained as yet unchanged" (p. 40).

He offers as an explanation that there are three substances present: (a) a swollen form of cell wall, which is not true cellulose, but is similar to the central portion of older cell walls of the tissue of the larger tangles; $(b)$ a substance coincident with mucilage; and (c) a substance akin to cuticle. Later the connecting strings are ruptured.

\section{In conclusion (p. 47), Bower states that}

"In all the cases described, the formation of the conceptacle is preceded by the decay of one or more cells which occupy a central position with regard to the changes which follow. The number of the cells thus removed is various, and the manner of their distribution is not constant. . . . . A point which is not so obvious, but which appears of similar constancy, is that the cell or cells which decay are in all cases members of a linear series. It depends upon the activity of division, in a direction tangential to the surface of the thallus, how this series is characterized; whether, as in Fucus, where the division is slow and even ceases, the apical cell of the series hangs behind the surrounding tissue; or whether, as in Himanthalia, where the division is often repeated, the series is elongated, and, protruding beyond the surface of the thallus, is called a hair"; and (p. 48): "This variation in activity of tangential division accounts for the want of uniformity in number of the cells thrown off in different species, and even in the same species. . . . . The differences in mode of development (in the early stages at least) depend upon the difference in activity of tangential division of the cells of the central series."

BOWER regards the hairpit as an incomplete conceptacle, but that "The homology of the two structures is so clearly proved that I shall be justified in proposing .... the name 'neutral conceptacle' (p. 44). I think it is important to convey at once the relation which appears to exist between them and the true conceptacle."

VALIANTE in 1883 (29) describes the method of development for Cystoseira and related genera. Primordia develop in the apical grooves of ultimate branches, a hollow being formed just as in 
early stages of hairpits. In either case, one or more peripheral cells at some point on the inner surface of the groove lose their power to increase in size and are left in a small cavity by active growth of surrounding cells. The initial (or initials) do not disintegrate, but by transverse divisions grow into hairs which project beyond the mouth of the conceptacle. He says he can find no traces, in his material, of decay of elements preceding formation of a cavity, as described by Bower for Fucus. He finds hairpits developed among the conceptacles at apices of fruiting branches, but that in such cases the cavity is less pronounced than usual. He considers these a convincing proof of the close relationship between hairpits and conceptacles.

Oltmanns ( $\mathbf{1 9}, \mathbf{2 0})$ considers that the method as described by Bower is essentially constant for all the Fucaceae, with very unimportant exceptions, namely, that the cells abutting on the "initial" have the chief work in organizing a conceptacle, sharing this with the "basal" cell, whereas the "initial" seldom remains intact, but either disintegrates or else grows into a hair ("überall kommt ihr zweifellos irgend eine nennenswerthe Funktion nicht zu"; 20, p. 516). Oltmanns regards the conceptacles and hairpits as homologous structures, but takes exception to BowER's conclusion that hairpits are "neutral (sterile) conceptacles," for he believes that the hairpits have become sexual (I9, p. 82).

BARTON in I89I (3) made the next contribution, in her study of Turbinaria. She found the conceptacles and hairpits developed in essentially the same way as described by Bower, VALIANTE, and Oltmanns, the "initial" cell being persistent. "The initial cell divides longitudinally, and both cells, after again dividing transversely near the top, grow into hairs, the upper division of the initial forming the swollen base of the mature filament. These filaments fill the fully grown conceptacle" (p. 224).

She objects decidedly to BowER's terms "neutral" and "sterile conceptacle" as "conveying an idea of abortive growth" (p. 223). Her view is that the two bodies are of "equal antiquity" and "a later development in the ancestors of the Fucaceae than the reproductive organs." "I consider neither form a development of the other, and the fact that one conceptacle contains reproductive 
organs, the other nothing but paraphyses, is an interesting point, but does not bear on the phylogenetic history of the conceptacles themselves." She then proposes the term "vegetative conceptacle" as meaning "those cavities in the thallus which have been developed only in a vegetative direction." In commenting on Barton's theory, Murray (18) says (p. 6o) "I know so little about the ancestors of the Fucaceae, that I must be content with a respectiful attitude toward this statement."

In their research upon Splachnidium, Mitchell and Whitting in 1892 ( 17 ) find that the conceptacle is developed by alteration of one of the epidermal cells, close to the apical cell, which becomes peculiarly modified but is inconsequential; however, they consider it the homologue of Bower's initial, although it takes no further part in developing the conceptacle, the real work falling to the neighboring cells.

In interesting connection with work on the conceptacle is that on hairtufts and sori in groups outside the Fucales.

Mitchell in I893, in a study of Hydroclathrus (I6), finds groups of hairs analagous to "Fasergrübchen" (cryptostomata) of the Fucaceae. In development they certainly resemble the conceptacles, and her description recalls ReINkE's work. She speaks of an isolated cell or group of cells which become separated from surrounding epidermal tissue. Transverse division results in formation of hairs from these isolated cells. Meanwhile growth of the thallus leaves the isolated portion in a slight depression. Later, the sporangia which are developed in close proximity around the hairpits mature, and after liberation of the spores the sporangial walls disappear and the basal cells originate new growth. Finally, all the sporangia disappear and these hairtufts, with central depressions, are left scattered over the thallus, persisting throughout the life of the plant. Mitchell concludes that although not a true conceptacle, such as in the Fucaceae, yet the growth of both hairs and reproductive organs is initiated by alteration in form and subsequent division of epidermal cells which might with truth be called "initial" cells. "My observations do not exclude the possibility of the initiative being taken by a small group of initial cells dividing simultaneously, instead of a single one." 
Murray (18) states that the development of both cryptostomata and conceptacles follow the method described by BowER. He quotes Bower and then adds "These words appear to me to be the true guide of those who investigate the development of such bodies" (p. 6o). In conclusion he states that comparison of the conceptacle of the Fucaceae with cryptostomata either in the heart of a sorus, as in Adenocystis and Hydroclathrus, or apart from the sorus, as in Alaria and Sacchorhiza, and with the situation in Asperococcus, in Cutleriaceae and in Dictyotaceae "points very significantly to a possible origin of cryptostomata. I anticipate, from further research into the development of these bodies, evidence that may enable us to dispense with the ancestors of the Fucaceae, of which, however, I would speak with respect" (p. 63).

BARTON in 1898 , in a study of Soranthera (4), Colpomenia, and Chnoospora (5), found an interesting development of reproductive bodies in connection with cryptostomata, giving further evidence along the line already noted by Murray in his study of Adenocystis. In each case a saucer-like depression initiated the central portion of a cryptostoma and later of a sorus with reproductive sacs, whether these latter be plurilocular or unilocular. The important fact is that both portions of the sorus always originate as modifications of the superficial layer of the vegetative body.

Holtz in I903, in his work with Pelvetia (II), describes a method of development little different in essentials from Bower's. Several epidermal ("initial"?) cells cut off a series of segments beneath to form a sort of pad of meristematic cells; then the external portions break down more or less, forming a cavity. The inner portions line the base of the cavity and later give rise to paraphyses and sex organs. Meanwhile unaffected epidermal cells continue division and cut off basal segments which become part of the cortex. "This new cortical growth stops abruptly at the conceptacle. In this way the cavity is deepened and a neck is formed, this neck being composed of epidermis-like cells. Original cortical rows are slightly deflected around the forming cavity, but later become deeply invaginated and thus aid in deepening the conceptacle" (pp. 35-36). 
SImons in 1906, in a study of Sargassum (27), claims a development of conceptacle "At variance with all the prominent characteristics . . . of the conceptacle as described by Bower." The initial does not break down, but is an active cell producing the entire conceptacle. Adjacent cortical tissue is in no way involved in the process (p. I69). "Both the conceptacles and cryptostomata originate in a single flask-shaped initial which develops the entire structure. The first division of the initial results in two unlike segments: a large lower cell which develops the walls of the conceptacle and cryptostoma; and an upper cell, the tongue cell, which either remains inactive, divides to form a short filament, or degenerates. The "initial" cell of Bower is apparently the tongue cell, a product of the true initial cell. The conceptacle and cryptostoma are undoubtedly homologous structures. Every stage of development in both structures is the same, from the appearance of the similar initial cells to the development of paraphyses in the cryptostomata and sexual organs in the conceptacle" (p. I79).

\section{Summary of literature}

The various theories described in the foregoing seem to resolve themselves into three categories: (I) the conceptacle or hairpit is a slight modification of the external layer of the thallus; this theory was held by KützING, SACHS, and LuERSSEN (I5); (2) the conceptacle is a product of one or more initials, which do or do not disintegrate; their basal segments form the basal portion, whereas adjacent cortical tissue completes the sides of the structure; this theory was held by Reinke, Bower, Valiante, Oltmanns, Barton, Mitchell, Whitting, Murray, Holtz, Falkenburg (7), and others; (3) the conceptacle is a product of a single initial whose segments develop the entire body; this is the theory of Srmons. All of these workers agree, more or less, that conceptacles and hairpits are homologous structures.

\section{Description}

In a study of three species of Fucus and of Splachnidium rugosum and a rather superficial examination of Sargassum filipendula and Hormosira, the writer found evidence which supports the early 
claim that the conceptacle is merely a slight modification of the original external layer of the thallus.

Following segmentation of the apical cell, in Fucus, some segment on the inner lip of the apical groove, close to the apical cell itself, ceases activity, and through failure to continue growth for a time is left in a depression by the active growth of abutting tissue. This inactive segment may then begin to break down in its external portion, without cutting off a transverse segment beneath to give a "basal cell" (figs. I-4, 5 c). Again, a basal

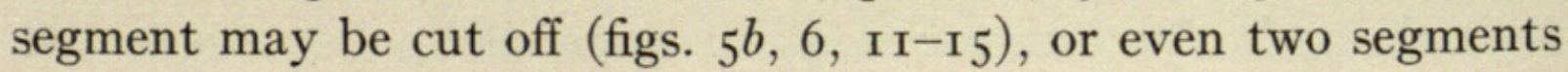
may behave in a similar fashion (figs. 8,9, ro). As the surrounding tissue comes to surpass the original inactive segment, the cells immediately abutting begin to break down in their external portions, as did the original segment (figs. I-I5). By continued involving of outer segments the cavity is gradually enlarged, and since the adjacent segments are always more active and therefore have greater turgor, the neck of the structure is narrow, whereas the basal part is broad.

Meanwhile, more and more of the outer portions of the cells involved break down, becoming mucilaginous and often showing several layers when stained with Lichtgrün (figs. 4, 6, 8, І0, I2, I4, I5). Ultimately, all except the portion immediately surrounding the nucleus having disintegrated, the original segments are left as mere lumps of tissue lining the cavity (figs. 6-15). These basal portions never lose their meristematic activity, but after a period of quiescence begin to put forth papillae as the cavity enlarges (figs. ı6, I7). These papillae develop into hairs by basipetal segmentation, and finally become mature, multicellular, unbranched hairs which fill the cavity and project beyond the opening, out over the surface of the thallus (figs. $15-18$ ).

Some time after maturity of the hairpit, these hairs are shed, and from the basal portions (of the original segments) new papillae put forth, this time to develop into hairs of a more delicate and fragile nature, often lost very shortly after (figs. 18, I9). Up to this stage there is no appreciable difference between hairpit and conceptacle. Moreover, further development merely offers a means of distinguishing antheridial from oogonial conceptacles, 
if the species happens not to be monoecious. Immediately upon loss of the fragile hairs described in the foregoing, or from basal portions which failed to develop them, new papillae develop which by their subsequent behavior indicate whether antheridia or oogonia are to come. In the former case, segmentation may continue until an elaborately branched and complicated structure bearing numerous antheridia is formed. In case of formation of oogonia, the papillae segment once, cutting off the pedicels and oogonia proper (fig. 20). Further development up to blocking off of 8 eggs (fig. 20) is as already described by many writers (FARMER and WiLliams 9, Oltmanns ig and 20, Strasburger 28, Yamanouchi 30, Simons 27, and others).

In Splachnidium rugosum the cavity is initiated by disintegration of an entire row of the thallus (and a terminal hair as well in some cases), pressure of active cells on each side reducing the disintegrating row to a long filiform structure which is left free subsequently by withdrawal of abutting cortical tissue in its effort to keep pace with active tissue toward the exterior. The abutting tissue at the external surface continues division and active growth, leaving the original initial row in a depression. Reproductive organs succeed a loss of hairs in the pit, just as in Fucus, except that here there are no evident antheridia or oogonia, but merely reproductive sacs.

Examination of Hormosira and Sargassum material seems to show the same behavior.

\section{Discussion}

It will be noted from the foregoing description that the sex organs appear after maturity of the hairpit, and, moreover, they appear in the hairpit itself. In other words, the hairpits and the conceptacles are certainly homologous structures, as already admitted by many, since one, the hairpit, is the juvenile stage of the other, the conceptacle. All hairpits, therefore, are potentially capable of producing reproductive organs.

Moreover, sex organs have actually been seen in hairpits, described by Srmons (27) as a "peculiar condition" (p. I73). She finds papillae and stalked cells like those which precede male 
organs in a conceptacle or like the male organs themselves. She considers this condition a proof that hairpits are derived from the conceptacle (p. I74).

The writer is strongly inclined to the belief that those forms which are reported to possess hairpits only, with no evident connection to reproductive organs, will, upon further investigation, show closest relationship to reproductive activity, as already proved in research upon forms of Ectocarpaceae, Laminariaceae, Dictyotaceae, and Cutleriaceae. To the writer the resemblance of Hydroclathrus (I6) to Fucaceae, where it is reported that after shedding sporangia basal cells originate new growth, is startling. In all the cases where similar sori are described, the origin is constantly from modification of the external layer, even when the writers themselves do not emphasize this fact. BoweR's description of Halidrys and Himanthalia (6) seems to the writer good evidence against his own theory, and the writer is inclined to the opinion that with technique as it is developed today, BowER would find the conceptacle of Fucus of quite the same origin as in Halidrys and Himanthalia. Even as it stands, several of BowER's drawings (pl. 5, figs. 2, 5, II) show a possibility of interpretation quite like that of the writer.

Sections made by the writer of the same species of Sargassum cast some doubt on the explanation offered by Srmons (27). Moreover, sections of young tips of Fucus vesiculosus give almost identical stages like those shown in her drawings of Sargassum (pl. Io, figs. I , 3, 5, 6, I 2, I 7, etc.). However, sections of later stages show subsequent behavior to be quite different from that described by Srmons, and to be as described by the writer for Fucus. It remains for further investigation to prove whether Srmons is entirely accurate in her description. It seems to the writer that what Simons interprets as segments of the basal portion of the "initial" are really the basal portions of original segments of the apical cell, similar in nature and behavior to the "initial."

As to the various terms suggested, BowER's "neutral conceptacle" ("sterile conceptacle") and BARTon's "vegetative conceptacle" are equally unhappy; if the body is a true conceptacle it cannot be "neutral," "sterile," or "vegetative." Since the 
modern trend is for simplicity rather than complexity, and since the hairpit is simply an early stage of the conceptacle, the writer is strongly inclined to reject both BOWER's and BARTON's terms and retain the simpler term "hairpit," an exact translation of the early German use of "Fasergrübchen." Bower's "central column" is explained by examination of figs. I3-I5. The old walls become mucilaginous and sometimes several layers of mucilage are seen between the meristematic portion and the "column."

\section{Conclusion}

There seems a clear line of advance from forms with continuous patches of hairs and reproductive organs, as Nereocystis and allied forms, to distinct sori, where the hairpit is the center of a reproductive group, as in some Ectocarpaceae, Laminariaceae, Cutleriaceae, and Dictyotaceae, to distinct conceptacles scattered over the entire vegetative body, as Splachnidium, Hormosira, etc., to a final distinct grouping at the apex of a shoot, as in Fucus, Pelvetia, and other Fucaceae, or on special side branches, as in Sargassum, Turbinaria, etc. Similar lines of advance are already commonly accepted for bryophytes and pteridophytes, in the one restricted to arrangement of sex organs, in the other to arrangement of sporangia. A striking parallel to Fucus is seen in Corsinia, Riccia, and allied forms, where, step for step, the development of the dorsal groove and subsequent appearance of sex organs (and even hairs) from the basal portion repeats the history of the development of the conceptacle of Fucus from an original segmentation of the apical cell. In this one sees a forceful illustration that plants again and again duplicate behavior in given conditions, even though in one case the plant may be a gametophyte and in the other a sporophyte.

\section{Summary}

I. The conceptacle originates as a slightly modified continuation of the external layer of the thallus, being segments of the apical cell whose basal portions are constantly meristematic and never entirely breaking down.

2. The hairpit is a juvenile stage of the conceptacle, the sex organs appearing in the same cavity as the mature hairs, but after their loss. 
3. A distinct phylogenetic series is seen in advance from continuous patches of hairs and reproductive bodies, to scattered sori, to scattered conceptacles, and finally to apically placed conceptacles or to conceptacles on specially developed side branches. All of these structures originate through modification of the superficial layer of the thallus.

Acknowledgment is due to Professors Coulter and ChamberLAIN for their many helpful criticisms throughout the progress of this work.

University of Chicago

\section{LITERATURE CITED}

I. Agardh, C., Species Algarum. I. Gryph. I823-1828.

2. Agardh, J. G., Species, genera, et ordines Algarum. I. London. 1848 .

3. Barton, E. S., A systematic and structural account of the genus Turbinaria. Trans. Linn. Soc. London II Bot. 3:21 5-226. pls. 14, I5. I891.

4. - On the structure and development of Soranthera. Jour. Linn. Soc. Bot. 33:479-486. pls. 23, 24. 1898 .

5. - On the fruit of Chnoospora fastigiata. Jour. Linn. Soc. Bot. 33 : 507-508. pl. 28. 1898 .

6. Bower, F. O., On the development of the conceptacle in the Fucaceae. Quart. Jour. Micr. Sc. 20:36-49. pl. 5. 1880.

7. Falkenburg, P., Die Algen im weitesten Sinne. Schenk's Handbuch der Botanik 2:159-314. Breslau. I9I2.

8. Farlow, W. G., List of marine algae of the U.S. Proc. Amer. Acad. 10: $35 \mathrm{Iff} .1875$.

9. Farmer, J. B., and Williams, J. L., Contributions to our knowledge of the Fucaceae; their life history and cytology. Phil. Trans. Roy. Soc. London B 190:623-645. pls. 19-24. 1898 .

10. Greville, R. K., Algae britannicae. Edinburgh. 1830.

I r. Holtz, F. L., Observations on Pelvetia. Minn. Bot. Studies 3:23-45. pls. 7-12. 1903 .

12. KJellman, in Engler und Prantl, Die natürlichen Pflanzenfamilien $\mathbf{I}^{2}$ : 1897.

13. KÜtzIng, F. T., Phycologia generalis. Leipzig. I843.

14. LeItgeb, H., Untersuchungen über die Lebermoose, Heft IV. Die Ricieen. pls. I-9. 1879 .

15. Luerssen, C., Handbuch der Syst. Bot. r : 1879 .

r6. Mrtchell, M. O., On the structure of Hydroclathrus. Phyc. Mem. 2: 53-56. pl. 14. 1893. 
I 7. Mitchell, M. O., and Whitting, F. G., On Splachnidium rugosum Grev., the type of a new order of algae. Phyc. Mem. I:I-Io. pls. I-3. I892.

18. Murray, G., On the cryptostomata of Adenocystis, Alaria, and Sacchorhiza. Phyc. Mem. 2:59-63. pl. 16. I893.

19. Oltmanns, F., Beiträge zur Kenntniss der Fucaceen. Cassel. I889.

20. - Morphologie und Biologie der Algen. Jena. I905.

21. Reinke, J., U̇ber Fucus vesiculosus. Bot. Zeit. 33:463-470. 1875; Nachricht K. Gesells. Wiss. Göttingen. 230-24I. I875; Jahrb. Wiss. Bot. го:317. 1876 .

22. — , Beiträge zur Kenntniss der Tange. Jahrb. Wiss. Bot. ro:3r7382. $\quad$ I 876 .

23. - - Entwickelungsgeschichte Untersuchungen über die Dictyotaceen des Golfs von Neapel. Nov. Act. Leopold 50: 1878 .

24. — - Atlas deutscher Meeresalgen. Berlin. I889-r892.

25. Rostafinski, J. T., Beiträge zur Kenntniss der Tange. I. Leipzig. r876.

26. SACHs, J., Lehrbuch der Botanik. Eng. ed. Oxford. I875 (pp. 226-229).

27. Srmons, E. B., Morphological study of Sargassum filipendula. Bot. GAz. 49: I6I-I82. pls. IO, II. I906.

28. Strasburger, E., Kerntheilung und Befruchtung bei Fucus. Jahrb. Wiss. Bot. 30:35r seq. I897.

29. Valiante, R., Le Cystoseirae del Golfo di Napoli. Fauna und Flora. Leipzig. pls. I-I5. I883.

3o. Yamanouchi, S., Mitosis in Fucus. Bot. Gaz. 47:173-I97. pls. 8-II. I909.

\section{EXPLANATION OF PLATES XIV-XVII}

The drawings were all made with the aid of the Abbé camera and reduced one-half in reproduction. For figs. $\mathrm{I}_{-1} \mathrm{8}$, the original magnification was 1050 ; for figs. 19-20, the original magnification was 535. Figs. I-I9 are of Fucus edentatus; fig. 20 is of Fucus vesiculosus.

FIGS. I $a-20 a$.- Sketches to show topography.

FIG. I.-The inactive segment of the apical cell; the external portion already shows a breaking down; adjacent cells also show inactivity in a similar way.

FIGS. 2-4.-Further breaking down.

FIG. 5.-(b) Original segment which has cut off a basal segment; (c) original segment with no such segment cut off.

FIGs. 6, 7.-Further stages of figs. $\mathrm{I}-3$.

Figs. 8-ro. Two or more arrested segments.

FIG. II.-Further stage of figs. $1-7$; basal portions about nuclei very distinct. clear.

FIG. I 2.-Further breaking down; involving of abutting cells especially

FIgS. 13, 14.--Showing how old walls are attached to "central column." 
FIG. I5.-Fragments in center due to disintegration of walls still attached to column in figs. $13, \mathrm{I} 4$.

FIG. I6.-Young hairs developed from meristematic basal portions of original segments.

FIG. I7.-Older stage of same.

FIg. 18.-Mature hairpit; meristematic portions of segments seen on side with papillae.

FIG. I9.-Older pit; long hairs falling off; meristematic portions of segments putting forth papillae and delicate hairs.

FIG. 20.-Mature conceptacle; delicate hairs being shed; oogonia in all stages from one-celled to complate blocking off of $8 \mathrm{eggs}$, developed by papillation and subsequent segmentation from meristematic portions of original segments; old hairs still seen about the ostiole, as well as fragments scattered through the cavity. 


\section{$2 \mathrm{BHL}$ Biodiversity Heritage Library}

Roe, Mabel Lewis. 1916. "The Development of the Conceptacle in Fucus." Botanical gazette 61(3), 231-246. https://doi.org/10.1086/331762.

View This Item Online: https://www.biodiversitylibrary.org/item/109212

DOI: https://doi.org/10.1086/331762

Permalink: https://www.biodiversitylibrary.org/partpdf/223758

\section{Holding Institution}

Missouri Botanical Garden, Peter H. Raven Library

\section{Sponsored by}

Missouri Botanical Garden

\section{Copyright \& Reuse}

Copyright Status: Public domain. The BHL considers that this work is no longer under copyright protection.

This document was created from content at the Biodiversity Heritage Library, the world's largest open access digital library for biodiversity literature and archives. Visit BHL at https://www.biodiversitylibrary.org. 